\title{
感覚の理論と社会の理論
}

一日本社会学史における元良勇次郎——

\section{大久保 遼*}

明治期に活躍した元良勇次郎は, 東京帝国大学で初めての心理学担当教授で あり，心理学実験室の開設に尽力するなど，一般的には日本における近代心理 学の祖として知られている. しかしながら, アメリカ留学中の学位論文におい て, 元良は社会学に焦点を当てたことがわかっており, 帰国後も黎明期の社会 学や社会心理学, 社会調查について論文を執筆するとともに, 1898 年には社 会学研究会の設立に発起人として加わるなど, 一貫して学術分野としての社会 学の確立に貢献した.

本稿では, これまで比較的知られてこなかった元良の活動の社会学的な側面 に焦点を当て, 膨大な業績のなかからその「社会の学」の構想を再構成するこ とを目指す，社会学史に扔いて元良が果たした役割は，アメリカ社会学を中心 とする心理学的社会学, および統計を用いた実証的な研究手法の導入といえる だろう，元良の構想において，実験心理学と社会学，感覚の理論と社会の理論 は，ともに総合的な「社会の学」のなかに位置づけられる。こうした元良の立 場は, 当時の主流派を形成していた建部稼吾らの国家主義的な社会有機体説に 対し批判的な役割を果たした。 日本における最初期の社会調查の実施にも尽力 し, また社会学研究会等を通じて後進の育成に努めたことも考光合わせるなら ば,「日本社会学の源流の 1 つとして, 元良の業績を位置づけることが可能 である.

キーワード : 元良勇次郎, 心理学的社会学, 日本社会学史

\section{1 問題の所在}

明治期に活躍した元良勇次郎は, 東京帝国大学心理学研究室の初代教授であり, 一般的には日本における近代心理学の祖として知られている. 死後すぐに弟子たち によって編纂された『元良博士と現代の心理学』（故元良博士追悼学術講演会編 1913）をはじめ, 心理学史におけるその業績についてはすでに詳細な検討が進んで いるものの, 元良が社会学史において果たした功績については, ごくわずかな例外

\footnotetext{
* 愛知大学文学部人文社会学科 okubo@vega.aich-u.ac.jp
} 
を除き, 詳らかとはいえない. しかしながら, アメリカ留学中に元良は, 社会学に 焦点の一つを当てた博士論文を執筆していたことが明らかになっており，帰国後も 黎明期の社会学や社会心理学, 社会調査について論文を執筆するとともに, 1898 年には社会学研究会の設立に発起人として加わるなど, 学術分野としての社会学の 確立に貢献したことが知られている.

本稿は, 元良の膨大な業績のなかから, 社会学との接点に当たる研究に焦点を絞 り，それを 19 世紀転換期の日本の学問状況のなかに位置づけることを目指す。元 良が模索した総合的な社会理論は，いまだ学として確立する以前の構想にとどまっ ており，また多くの点において時代的な限界があることも否定できない.しかしな がら, 社会学が確固として自律する以前の広がりを有しているからこそ, その形成 過程をたどる試みは，19 世紀転換期における諸学の交錯の一端を描きだすことに つながるだろう。

日本心理学会編（1980）などの心理学史において，元良は日本における近代心理 学の端緒という位置づけを与えられてきた。 しかしこれまでの研究の多くは, 帝国 大学における研究室の開設やその学説の紹介にとどまっており, 日本近代における 心理学という学知の形成において, 元良が果たした役割を問う研究が本格的に進展 したのは, 1990 年代以降になってからだといえるだろう（苧阪 1998; 艼阪編 2000; 大山 2001). とりわけ最も詳細に元良の業績を整理し, その総体を心理学史 に位置づけたのが，佐藤達哉による博士論文とそれを基にした大部の著作である (佐藤 2002). 佐藤は, 元良の生涯, 業績リスト, 学説に詳細な検討を加え, 多く の新資料を提示するとともに，心理学の周辺領域をふくむ業績の再評価を行った.

しかしながら佐藤は，「従来はホールと共著の精神物理学論文（Hall and Motora 1887）が博士論文と思われていたが, 実際の博士論文は哲学的もしくは社会学的な ものであった」（佐藤 2002：100） と指摘しているものの, その内容の詳細や社会 学における業績への言及は十分になされていない.

一方，元良は日本における社会心理学の出発点としても位置づけられてきた。た とえば高橋徹は, 元良が社会心理学という名称を最初に使用したことを指摘し, 先 駆者としてその業績を高く評価している。とりわけ論文「心理学と社会学の関係」 について,「社会物理学としての社会学的アプローチと精神物理学としての心理学 的アプローチとの会合の論理的必然」が論じられた画期的な業績と評価している (高橋 1965: 475). また佐原六郎は元良の社会心理学的見解に注目し, その論理に ついて内在的な分析を行った上で, 1890 年に著された元良の『心理学』を，「わが 国社会心理学発足の第一歩」と位置づけている（佐原 1987：22,1968）.

本稿は, 高橋や佐原の議論を引き継ぎながら, 19 世紀末から 20 世紀初頭の学問 状況のなかで，総合的な社会理論の構築を目指した元良の活動に焦点を当てたい. これまで積極的に論じられてこなかった社会学と元良の関係に注目することで, 本 稿は, 19 世紀末のアメリカ社会学や日本における心理学的社会学の導入の流れに その業績を置き直し, 同時代の諸学の交流と社会学的な知の形成に対して元良が担 
った役割を明らかにする。

\section{2 アメリカ社会学の影響}

\section{1 アメリカ留学と実験心理学}

元良勇次郎は, 1858 （安政 5）年に摂州三田藩（現在の兵庫県三田市）の儒学者 である杉田泰の次男・杉田勇次郎として生をうけた．幼少時から三田藩藩校の造士 館で儒学と洋学を, 蘭学者の川本幸民が主宰した英蘭塾で英学を学ぶ.しかし 1871 年, 若くして父の病死により杉田家は没落, 家を出て宣教師ジェローム・デ イヴィス宅に住み込みで働くことになった。これを機にディヴィスより英語を学び, 後の学問形成に影響を与えた学術書を読み進めるとともに, キリスト教の洗礼を受 けている（荒川 2000; 佐藤 2002; 故元良博士追悼学術講演会編 1913). 後年は学 問的立場を優先し信仰からは距離を置くことになるが, とくに初期の元良の学問形 成は，キリスト教と明治期のキリスト者のネットワークから大きな影響を受けるこ とになる1).

1875 年に新島襄とディヴィスが開校した同志社英学校の第 1 期生となり, 1880 年には東京大学に理科選科生として入学, 物理学と数学を学ぶ.この頃から留学へ の志を抱き，自ら製作したタイプライター式計算機により渡航資金の捻出を目指す が, 挫折. 翌年には退校している. その後, 1881 年に東京英学校（後の青山学院） 設立に貢献. しかし留学を諦めきれず 1883 年に渡米するが, 資金難のため特別学 生（現在の聴講生）としてボストン大学に入学. 翌々年, ジョンズ・ホプキンス大 学に正規学生として転学, 1886 年にはフェローに選出され奨学金を得て学んだ (佐藤 2002; 故元良博士追悼学術講演会編 1913).

1887 年には American Journal of Psychology 創刊号に論文 “Dermal sensitiveness to gradual pressure changes”（圧力の漸次変化に対する皮膚の感受性）を, 心理学・哲学史担当の教授として在籍していたスタンレー・ホールとともに発表. 草創期のアメリカ心理学にその名を刻んでいる (Hall and Motora 1887) ${ }^{2)}$. 同年, 博士論文 “Exchange, Considered as the Principle of Social Life” (社会的生活の原 理としての交換）により博士号を取得（Motora 1888）。博士論文の関心は，交換を 基礎とする社会理論の構築にあった．近年指摘され始めているように，これまでの 伝記や留学前後の記述は, 帰国後の心理学者としてのキャリアを前提とするあまり, 心理学に関連する事実ばかりが中心的に取り上げられる傾向にあった（佐藤 2002; 大泉 2013). しかしながら,こうした記述では留学中の元良が最終的な学位論文で 社会学に焦点の 1 つを当てた経緯は十分に理解できない.

\section{2 黎明期のアメリカ社会学}

ジョンズ・ホプキンス大学時代の元良の関心を理解するためには, 同時代のアメ リカ社会学の流れを確認する必要がある.アメリカにおいて初めての独立した社会 
学部がシカゴ大学に設立されるのが 1892 年, American Journal of Sociology が創 刊されるのが 1895 年のことである. 元良が留学した 1880 年代末のアメリカは心理 学の草創期だっただけでなく, 労働環境の悪化と社会問題の認識, 社会改良運動や 社会調査への関心の高まりとともに, 学問領域としての社会学が形成されていく時 期に当たっていた（志邨 1993）。こうした 19 世紀末におけるアメリカ社会学の源 流には,「ドイツ歴史学派」と「社会的キリスト教」の潮流があったことが指摘さ れている（宇賀 1976, 1990）。

宇賀博によれば, 経済学におけるドイツ歴史学派は, 古典派経済学の行き過ぎた 個人主義と自由主義的傾向を批判, 経済活動における歴史的・社会的背景に注目し, 倫理的アプローチや統計を重視した。一方, 社会的キリスト教の運動は, 古典派経 済学による無制限の競争の正当化への異議, 産業革命による労働と資本との対立の 問題化，抑制なき資本主義の経済倫理に対する批判といった課題を共有しており, これらを乗り越えるため, 社会科学とりわけ社会学を重視する立場を示した。両者 は同時代の同じ基盤の上に成立しており，この 2 つが交錯した地点に，ハーバー ト・スペンサー流の社会ダーウィニズムに対する批判として, アメリカ社会学が立 ち上がったのだという（宇賀 1976: 315）.

1880 年代後半は, アメリカで社会的キリスト教が強い影響力を有していた時期 であり，プロテスタントであった元良もこの潮流の影響を受けていた．とくに元良 がジョンズ・ホプキンス大学に転学したのは, ドイツ歴史学派の経済学者でこの運 動の主導者の一人であったリチャード・イリーが財政学と経済学担当の教授として 在籍していた時期に当たる. 当時, イリーはアメリカ経済学会の創設にかかわり,

女性・若年労働の問題を批判してウィスコンシン州の革新主義改革に協力するとと もに，社会学の重要性を訴えていた（志邨 1993: 121).イリーはハイデルベルク 大学でマックス・ヴェーバーの前任を務めたカール・クニースの下で博士号を取得 しており, 古典派経済学への批判から社会学を重視, 「過去のキリスト教会の誤り や困難の主たる説明は, 神学を賛美し社会学を無視した点に求められる」(Ely 1889：86）と主張し，1893 年にはキリスト教社会学研究所を設立している（武 1978).

帰国後の心理学者としての側面が強調される際には見落とされがちだが，元良は 留学中に経済学の講義を積極的に受講しており, とくに学位論文を執筆した 1887 年度には, イリーの「財政学 Finance」(週 3 コマ),「経済学 Political Economy」 （週 5 コマ・ゼミナール）を中心に履修している（Johns Hopkins University Circulars VII: 6). 実際, この時期にジョンズ・ホプキンス大学に留学していた長瀬鳳 輔によれば, 元良は「大学ではイリーという先生に学び, その人の『近世社会主 義』という小さな本を読んで大いに感心していた．あちらでは晚飯後 1 時間位はい ろいろの話をして暮すのが習慣であったが, その頃, 何時も元良氏と社会問題に就 て議論をした」（故元良博士追悼学術講演会編 1913：144）という3）。したがって, 19 世紀末のジョンズ・ホプキンス大学において, 元良はホールの下で先進的な実 
験心理学を学ぶだけでなく, ここまで明らかにしてきた通り, イリーの著作や講義 を通じて, ドイツ歴史学派および社会的キリスト教の議論から当時のアメリカ社会 学の潮流を受容していたのである.

\section{3 社会的生活の原理としての交換}

元良の博士論文「社会的生活の原理としての交換」は 1888 年に受理され, 博士 号が授与された. 大学の記録では, 学位論文の主題は「哲学史, 心理学, 経済学 (History of Philosophy, Psychology, Political Economy)」であると記載されている (Johns Hopkins University Circulars VII：105)。あらためて確認すれば，アメリカ で最初の社会学部がシカゴ大学に開設されたのは 1892 年になってからであり, 当 時ジョンズ・ホプキンス大学には社会学科や単独の社会学の講義は存在せず, イリ 一が担当していたのは経済学や財政学であった。こうした時期に元良はその博士論 文において, 交換を中心として市場や流行, 組織を論じ, 社会学 (Sociology) と いう学問が対象とする範囲を定めるという, きわめて原理的な議論を展開した (Motora 1888). 目次構成は以下の通りである.

\begin{tabular}{|c|c|c|}
\hline 第 1 章 & 因果律と目的性 & Causality and Finality \\
\hline 第 2 章 & 人間の概念 & Conception of man \\
\hline 第 3 章 & 人間の概念（続） & Conception of man (continued) \\
\hline 第 4 章 & 富の概念 & Conception of Wealth \\
\hline 第 5 章 & 社会の概念 & Conception of society \\
\hline 第 6 章 & 交換の条件 & Condition of exchange \\
\hline 第 7 章 & 交換の過程 & Actual process of exchange \\
\hline 第 8 章 & 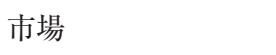 & Market \\
\hline & 流行と退潮 & Current and counter current \\
\hline 第 10 章 & 組織 & The institute \\
\hline 第 11 章 & 組織（続） & The institute (continued) \\
\hline 第 12 章 & 自然と社会 & Nature and society \\
\hline & 社会学の範囲 & Province of sociology \\
\hline & 社会学の範囲 (続) & Province of sociology (continued) \\
\hline & 社会学の範囲（続） & Province of sociology (continued) \\
\hline
\end{tabular}

実験心理学やカントの哲学に基づいて人間の概念が論じられた後, 人間の基本的 な特性としての社会性や社交への欲求が指摘され, 交換をべースに市場と流行を位 置づけ, 自然科学と社会科学を区別し, 社会学の範囲が定められる. 富の概念, あ るいは市場のメカニズムや組織の社会性への着目は, ドイッ歴史学派の議論からの 影響が見受けられる。 また人間の概念を定めるに際して, 実験心理学の知見が導入 されるなど, アメリカ留学において学んだ自然科学, 社会科学双方の知識を統合し, 
体系的に把握することが目指された論文といえよう。ただし，この学位論文の主軸 となった，交換を中心とした社会理論という発想は，実はアメリカ渡航以前に遡る アイデアである。

元良は, 留学の直前に「知識交換論」を『六合雑誌』に発表, また 1884 年には この「知識交換論」を補論として附した初の著書『教育新論』を刊行している. 元

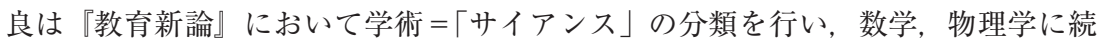
いて，すでに世態学について論じている，元良によれば，プラトンやアリストテレ スも世態学の必要を論じていたが, その原理を発見しておらず, 世態学は未だ一個 の科学にはならなかった。これに対し「仏国の碩学コムト」は社会の変遷に一定の 法則を発見しょうと努め, 世態学の基礎を築き, そして「高名なるスペンサル氏に 至り, 化進の原理を社会に応用して, 世態学の一科をなし, 人間社会の簡より雑に 移るの定則を立てたり」と解説している（元良 1884: 55). また元良は, 数理の学 が物理学だけでなく, 最も複雑な世態学に統計という形で導入されつつあることに 触れ, 「社会の事実に数理を応用したるは, 近来の美事」であると述べた（元良 1884: 94).

『教育新論』が発表されたのは，1881 年に東京大学の哲学科で世態学の講義が開 講されてから，1885 年にそれが社会学と改称されるまでの間, sociology (sociologie）の訳語として世態学と社会学とが混在していた時期に当たる（東京大学文学 部社会学研究室編 1954: 5-6). この時点で, 元良は狭義の sociology を世態学とし, これに経済学 (理財学) や政治学を加えたより包括的な社会科学に近い意味で「社 会学」を用いている（元良 1884: 105）. また元良は, 「精神あるいは社会の学術を 修めんとする者は, 必ず先ず物理の学を修めざるべからず」（元良 1884: 102）と 述べ, 徒に専門に走らず, 物質の学から精神の学, そして社会の学へと段階的, 総 合的に学ぶことを推奨している. したがって, 留学以前に数学と物理学を, またジ ヨンズ・ホプキンス大学に在籍した前半に生理学や哲学, 心理学を, 後半に財政学 や経済学を学び, 最終的にそれらを総合した上で, 学位論文において社会学という 学問が対象とすべき範囲を論じたことは, 『教育新論』の学問論を体系的に具現化 したものとみることができる.

また元良は「知識交換論」のなかで, 貨幣が社会のなかで交換されることによっ てのみ意味をもつのと同様に, 知識も「もし徒にこれを各自の脳中に貯え置くとき は無用物にして全く知識無きが如し. 唯々これを他人に伝えあるいはこれを実地に 施して始めてその用をなすのみ」（元良 1884：120）と主張し,「文明開化」と「社 会の進歩」のためには, 「運輸交通」「物品の交易」と並んで「知識の交換」が重要 であると論じた.すなわち，この「知識交換論」は，元良にとってのコミュニケー ション論であり, 知識の交換とその様式に注目して「社会の進歩」を論じたものと 考えることができる．元良は知識交換を以下のように分類した（元良 1884：123）.

第一，言語を以て知識を交換すること 
（イ），朋友相会し互に談話するとき

(口)，教場にて教員生徒に教授するとき

(ハ)，演説者聴衆に対し演説するとき

第二，文字を以て知識を交換すること

(イ）新聞雑誌の類 記者 読者

(口) 書籍

記者 読者

「知識交換論」は声と文字をめぐって明治期に展開されたメディア論としても興 味深いが, しかしその後の議論は精読を推奨する読書論に逢着し, 『教育新論』本 論における学術の分類や世態学, 社会学の議論とは直接結びつけられてはいない. したがって，『教育新論』および「知識交換論」は，著者の博識を垣間見せるとは いえ，あくまで啓蒙的な教育論・学問論の範疇にとどまるものであったといえる. しかしながら, 交換を基礎とする総合的な社会理論の構想は, 明らかに留学以前の 論文にその萌芽がみられるものであり, ジョンズ・ホプキンス大学に提出された学 位論文は，アメリカで学んだ社会科学のディシプリンと概念によってその発想を大 きく展開し, 学術的に再構成したものとみなすことができる. 従来の心理学史にお いては, 留学以前の愛読書とされるウィリアム・カーペンターの『精神生理学の原 理』が学問形成の出発点に位置づけられることで, 帰国後の心理学者としての業績 との連続性が説明されてきた（佐藤 2002: 70). しかしながら, 留学以前の著作か ら学位論文への展開を仔細に検討することで浮かび上がるのは, むしろ心理学と社 会学の双方を含む総合的な社会科学に対する元良の一貫した関心である.

したがって，「心理学者である元良がなぜ社会学の論文によって学位を取得した か」という問いは，後の学問の分化や大学での担当講座を前提とした転倒といえる. 元良は留学以前から交換をべースとした社会理論に関心をもっており，19世紀的 な学問状況のなかで, 心理学と社会学, 物質・精神・社会の関係を視野に収めた総 合的な「社会の学」を目指していたのである，その構想はまさに 19 世紀的な限界 を有しているとはいえ, 後の個別化したディシプリンの視点からのみ論じるならば, その試みの総体を矮小化することになるだろう。

\section{3 社会的感覚の論理}

\section{1 総合的な学知としての社会学}

アメリカ留学からの帰国後, 元良は東京英和学校に赴任し, 1889 年には外山正 一と正則予備校を設立，校長を務めた（佐藤 2002：108-9)。この時期の元良はア メリカ留学で身につけた実証的な学術の手法による新しい教育の推進を志していた のであり，「決して実験心理学をわが国に移植することを決意して帰国したわけで はなかった」(大泉 2013：xv). 実際，1889 年には東京英和学校で社会学と哲学史 を教えていたという（故元良博士追悼学術講演会編 1913：422）。たとえば講演 
「社会の道徳と自殺との関係」に扔いて元良は, イタリアの精神医学者エンリコ・ モルセリの著作を取り上げ，いくつかの統計を実際に示しながら,「統計と社会の 密接なる関倸」について論じた。元良は以下のように述べている.「確実なる事柄 と, 精密なる統計とを基礎とし, 以て確乎たる帰納法に據り着実温厚の議論を吐き, 以て世に所謂 書生の机上論を避けざるべからず」（元良 1889a: 90).

1888 年に精神物理学の講義を担当したことを契機に, 元良は 1890 年に東京帝国 大学の文科大学教授として, 哲学科において心理学を講じることになった. 1893 年には講座制の導入に伴い, 心理学・倫理学・論理学の第 1 講座を担当している. しかしここまで確認してきた通り, 元良の留学前後の関心からすれば心理学の担当 は必ずしも順当とはいえず，これはすでに文科大学では外山が社会学を担当し， ス ペンサーを講じていたこと, そして外山は元良が身につけた自然科学的な実験の手 法を評価しており，哲学科に実験を導入する意向があったことに起因するものと考 えられる（故元良博士追悼学術講演会編 1913：150）。しかし元良はその後も繰り 返し社会と社会学を論じ, 総合的な学知としての社会学という構想を保持し続けた. たとえば 1891 年の論文「社会学の範囲扔よび性質」において，元良は以下のよう に述べている.

社会学は学問の王にして, 社会の現象は実在の最も完全なるものなり.すべ てその他の者は, 絶対的の価値, 絶対的の存在を有することなく, ただ相関的 存在, 相関的価值を有するものにして, これを社会活動の一補助としてその本 質を完うし得るものと云うべきなり。これ余が社会学に対するの意見の大意な り。（元良 1891: 1015-6)

この論文において元良は, 社会学が「学問の王」であり, 社会の現象こそが「実 在の最も完全なるもの」であると論じ, 歴史学, 心理学, 物理学 (物質学) 等を包 含する領域として社会学を位置づけている（元良 1891：1015）。また 1897 年に刊 行した『心理学』においても, 以下のように社会学への希望を述べている.「いわ ゆる社会学とはこれを広義に用いたるものにして, 人事界における総べての現象を 抱含したるものなり．社会学はその研究未だ進まずして今日にてはなお一科となす べき価值なしといえども，将来大に望を属すべきものあり」(元良 1897a: 3).

\section{2 社会的感覚の論理}

元良はこうした総合的な学知として社会学を論じ, そのなかで心理学を捉え, 社 会の学と人間の学の総合を模索していた. 1889 年の論文「心理学と社会学の関係」 において元良が論じるところによれば，社会現象とは個人の主観的な精神現象のこ とではなく, 複数の個人の間に生じる現象であり, 客観的なものである. これが社 会学の対象となる. しかし人間とは, 「主観客観相合したるもの」すなわち, 主観 的な精神現象と客観的な社会現象の双方に属する存在である. したがって, 人間に 
ついて知るためには心理学と社会学の双方が必要であり, 社会現象を分析するため にも, 主観的な精神現象の原理を把握しなければならない（元良 1889b: 708-9).

社会の学その数多しといえども, 到底社会の現象を研究するの学なれば純粋 なる精神の学に非ず。また物理のみにも非ず。精神界と物世界との関係及び人 と人との間に行わるる物力の関係を研究するものなれば, 政治, 法律, 経済, 歴史, 宗教, その他総て社会に関する学識を得んとするには, 必ずまず心理学 の原理を知らずして社会学を学ぶ者は, 数理を知らずして機械学を学ばんとす る人に異ならず。（元良 1889b：716；傍点は引用者）

したがって, 社会現象を研究するためには,「人と人との間に行わるる物力の関 係」だけでなく「精神界と物世界との関係」を理解しなければならず,「政治, 法 律, 経済, 歴史, 宗教, その他総て社会に関する学識」を得るためにも, 心理学を 学ぶ必要がある. したがって元良にとって, 社会学と心理学は切り離すことができ ず,ともに政治・経済・歴史等を含んだ総合的な「社会の学」の探求のなかに位置 づけられる.こうした視点から 1890 年代に元良が集中的に取り組んだのは, 社会 現象と精神現象, 感覚の理論と社会の理論の総合とその境界領域の模索であった. 元良は 1890 年に著された『心理学』のなかで,「社会的感覚」の概念を媒介にして この問題を論じている.

一個人に各特有性あり。その特有性に由って各人の挙動にまた種々の差異を 生ず…ㄹれと同じく社会的感覚なるものは一社会あるいは一国家の特有性な り。しかしてこの感覚は固より一個人の亡ぶると共に亡ぶるものにあらず。社 会の存在せし以来漸々に発達したるものなり.今日において存在するものは, その発達の結果なるがゆえに, また今後も我等の死する後, 永く社会とともに 存在するものなり。（元良 1890：188-9）

個人にはそれぞれ特性があり, その特性に従ってその行動にも差異が生じる. 元 良によれば, 社会的感覚もこれと同様に 1 つの社会に特有の感覚であり, そこに属 する個人が滅したとしても消えることはない. 社会的感覚は個人とは独立して存在 するもので, 1 つの社会が存在する間は決して消滅することがない. それでは, 社 会的感覚は個人とはまったく無関係に存在するものであろうか.

元良によれば,「社会的感覚」は個人の性質であると同時に関係に基づく感覚で ある.これは非常に位置づけが難しいが, ある学者は 1 つの種族には必ず同じ社会 的感覚が備わっており, これは個人の精神とは独立して存在し, 社会の活動ととも に変化するものであると主張している。 また他の学者は, 社会的感覚は一個人を離 れて存在しえず，ただ個人が寄せ集まったものを抽象的に言い表した総称に過ぎな いと主張している（元良 1890：189）。しかし元良によれば, どちらの意見も極端 
である，社会的感覚は，一個人を離れて存在するものではなく，また単なる個人の 集合でもない（元良 1890：190）.

たとえば愛情は，一個人の性質でありまた二者間の特別な関係性によって生じる 感覚である，二者の関倸性が変われば，その質も変化する，これと同様に，社会的 感覚も個人に根差すものではあるが, 複数の個人が集まり, ある形式の関倸性を組 織したときにはじめて生じるものであるという（元良 1890：191）。元良はここで 「社会的感覚」という概念を用いて, 心理学と社会学の総合を模索している ${ }^{4)}$. ま た元良は前掲の論文「社会学の範囲抢よび性質」に扔いて, 社会学の一分野として の社会心理学を論じ（元良 1891: 1012）, 1897 年の『心理学十回講義』のなかでも 「名誉心, 交際の快感, 社交の流行, 風俗, 流行唄, 舞踏狂の伝染」といった「社 会的心理現象」の研究は, 心理研究の補助となると同時に, 社会学の研究の上でも 必要であるとしている（元良 1897b: 16）.

20 世紀初頭の日本では, 個人の心理と社会の関係を主題とする社会心理学，あ るいは集合的な心理現象に焦点を当てる群集心理学, 民族心理学の学説の紹介, 翻 訳書の刊行が相次いだ．たとえば，徳谷豊之助『社会心理学』(1906 年), 遠藤隆 吉『社会心理と教育』(1908 年), 小林郁『社会心理学』(1909 年) が刊行され, 樋 口秀雄は『社会学十回講義』（1912 年）のなかで「社会意識」「社会と心理的理法」 を論じた。また，塚原政次『ルボン氏民族心理学』(1900 年), 谷本富『群衆心理 の新研究』（1908 年）など, ギュスターヴ・ル・ボンの概説書や翻訳も次々と刊行 されている.

元良はこれらに先立つ 1891 年の前掲論文に扔いて, 社会心理学という言葉を用 い, 1895 年には「社会心理学」と題した講演を行っている (元良 1895). 塩沢昌 貞の回想によれば, 1894 年から 1897 年にかけて塩沢と三浦周行は元良から社会学 や経済学の研究の助手を依頼され，「風俗，人情，伝説，宗教など」について広く 研究の素材を提供していたという（故元良博士追悼学術講演会編 1913: 159）。ま た当時学生だった桑木嚴翼は 1890 年代半ばの心理学の講義について,「当時先生は 社会心理学, 経済の心理というような問題を主として研究されていたので, 我々は 3 年では期待していた実験心理学を聞くを得ず, 多少失望していた」（故元良博士 追悼学術講演会編 1913：386）と語っている。 この時期の元良の関心は実験心理学 よりも, 明らかに社会心理学ないし社会学と心理学の総合にあった.

1900 年に元良は, 遠藤隆吉の翻訳で出版されたヘンリー・ギディングスの『社 会学』の閲読を担当している. ギディングスは心理学に基づく社会学を提唱, 『社 会学』の序文で「社会学は心理学的科学なり」(Giddings 1896=1900：1）と宣言し ており，遠藤はこの書の翻訳において「社会意識」という訳語を創出したといわれ る. またこの時期には, 大学総長への就任を機に社会学講座を離れた外山の後任と して, 元良と同じく東京英和学校からジョンズ・ホプキンス大学に進んだ高木正義 が, 社会学講師に着任している. 高木はジョンズ・ホプキンス大学で Ph. D. を取 得した後, ギディングスが在籍していたコロンビア大学で学んだ（川合・竹村編 
1998：98)．1897 年の着任から建部逰吾が留学より帰国する 1901 年までの間, 高 木は社会学講座の事実上の担任を務め, 主にギディングスの社会学を講じている (東京大学文学部社会学研究室編 1954: 9). この間, 高木は元良と行動をともにし, 後述するように両者は社会学研究会の発起人として名を連ね, 心理学的社会学と実 証的研究の重要性を論じた. 高橋（1965）や佐原（1968）が指摘するように，元良 は社会心理学を早い時期に論じたが，それだけでなく，ここまで明らかにした通り， ギディングスの『社会学』の翻訳に関わり, 遠藤や高木など後進とともに心理学的 社会学の導入に努めたのである.

\section{3 民族心理学の困難}

早い段階で, 社会心理学や社会的心理現象を積極的に論じた元良だが, 次第に集 合的な心理現象の研究に対して慎重な立場をとりはじめる. 晚年に近い 1907 年の 『心理学綱要』において, 元良は以下のように民族心理学の困難について述べてい る.

民族心理学市研究は困難なり。さて社会心理, 民族心理等の側の研究は興味 のある研究ではあるが一般心理学の根本が確立して来れば漸々にこれらの研究 にも移れるけれども, 根本が定まらないでこういう複雑な事実を研究すること は，余程困難であると思う。（元良 1907：39）

元良によれば，いまだ一般心理学が確立しない段階で，社会心理，民族心理のよ うな複雑な事象を研究することは困難であるという。また同書において, 近年の研 究者は「顕微鏡を忘れる傾向」にあり,「現時欧羅巴, 亜米利加の心理学者が極端 に走り, 内省法を十分に練習して居ないかのように思わるる」ことがあると述べて いる（元良 1907：34）. いち早く社会心理学を提唱し, 社会的な心理現象について 論じた元良は, 民族心理学や群集心理学の紹介が進んだ 1900 年代において, むし ろ個人の主観的な心理現象や哲学的心理学を重視し, 集合的な心理現象の研究に対 して慎重な姿勢に転じたのである.

この転換の理由について, 元良は多くを語っていないが, その背景はともにギデ イングスの翻訳に携わった社会学者・遠藤隆吉の議論を参照すると理解しやすいだ ろう。遠藤は元良が「民族心理学の困難」を論じたのと同じ 1907 年の『近世社会 学』において, 社会の基礎は個人におかれるべきであるとした上で, 当時の社会学 においてへゲモニーを握っていた社会有機体説を以下のように批判している．「社 会有機体の説たるや, 社会を以て一団体となし一の渾一体となす者にして, その幼 稚なる，ほとんど一顧の価なし」（遠藤 1907：20）。これは「社会は渾一体」であ り「社会は有機体なり」と論じた建部逰吾の学説への痛烈な批判であり, スペンサ 一流の社会進化論を国家主義へと短絡した社会有機体説への, 心理学的社会学派か らの批判を代表したものといってよい. 
すなわち元良や遠藤, 高木が導入を進めた心理学的社会学においては, まず個人 を基礎として認め, その関係ないし集合として社会の特性を論ずるのが基本的な構 えであった. しかし日本に社会学が導入される過程で主流となったのはスペンサー の学説であり, しかも建部流の社会有機体説においては, 社会が有機体的な国家観 や前近代的な共同性と結びつけて理解され，個人が融解した渾一体のごとく論じら れた. 1901 年, 建部の帰国と入れ替わるようにして高木が退職した後, 1903 年に は建部によって文科大学に社会学研究室が開設されるが, そこで講じられたのは以 上のような社会学だったのである. 高木が社会学講座を離れ, 遠藤が社会有機体説 を痛烈に批判, 元良が民族心理の研究に慎重な姿勢へと転じたのは, このような時 代のことであった，次節では，こうした状況を踏まえ，元良が示した社会学的な見 解と同時代の社会学界における立場について詳述する.

\section{4 社会学研究会の設立}

元良と日本の社会学の関係において特筆すべきは, 社会学研究会の設立である. 元良が心理学者として活動した時期は, 日本の社会学の黎明期に当たっており, 各 種の研究組織や学術誌が創設された時期でもあった. 急速に産業化が進んだ 19 世 紀末の日本は, 元良が留学したアメリカと同様, 都市の労働環境の悪化, 社会問題 と社会運動の発生といった状況に直面しており, 社会学の導入だけでなく, その知 見を用いた日本社会の分析の必要性が認識されはじめていたのである. 元良もまた 学問としての社会学を講じるだけでなく, 1893 年の講演において「日本社会の法 則」を科学的に研究することが重要であると論じている，元良によれば，明治の日 本は「社会学者の大試験場となることが出来る」のであり,「西洋の一般の学理に 通じた所のその目を以て我々がこの日本の組織と云うことを研究して, 日本の社会 学と云うものを㹉える」必要があるという. そして日本社会の研究は, 日本のみな らず世界の学術のためにも必要であると元良は講じた（元良 1893: 31-2）.

1896 年には社会政策学会が設立, 1897 年には社会問題研究会, および「社会学 の原理, 社会主義, 社会問題等を攻究するを以て目的」とする社会学会が立ち上げ られた（河村 1973：187）。これらの組織はそれぞれ，政策科学としての社会学， 社会問題の解決と社会主義運動としての社会学, 学問領域としての社会学を志向し ていたと大きくまとめることができる．しかしこの時期には，三者は明確に区別さ れていたわけではなく，人的な交流も盛んに行われていた（河村 1973: 185-8).

この社会学会の解散後に発足したのが, そのメンバーや問題関心を引き継いで発足 した社会学研究会である.

元良は初期の論文で社会主義の紹介を行っており, 社会主義研究会にも一時参加 していたが, この研究会は内部分裂を繰り返したため脱会している (Piovesana $1963=1965:$ 57). 元良は論文「富と道徳」において,「努力と報酬の不平均」に対 しては急進的な立場として「虚無党」(無政府主義) と「社会党」(社会主義)があ 
るが，自身は漸進的な社会改善を目指すべきとの立場を採ると論じている（元良 1889c)．この立場に最も近かったのが, 「社会学の原理, 社会問題及び社会改善策 を研究する」ことを目的として，1898 年 11 月に設立された社会学研究会であった (『社会』1(1)：90). 元良は高木正義らとともに発起人としてこの研究会の立ち上 げに参加するだけでなく，機関誌にも積極的に寄稿している.

1899 年に創刊された社会学研究会の機関誌『社会』第 1 号に掲載された論文 「生活の標準」において元良は, さまざまな社会的活動を統計的に把握することの 必要を論じている，それによれば，財産の多夏や婚姻の状態あるいは道徳や教育を 1 つの指標として，社会の標準を測ることができると考えられ，今後統計を用いた 研究が進むことが期待される. また元良は日本の中産階級の特徴は思想の標準，す なわち主義が定まっていない点にあるとした上で, 今後「社会的倫理の研究と云う 事を社会が要求して居るのではなからうか」（元良 1899: 24）と指摘している.

こうした元良の問題関心は，日本における先駆的な社会調查へと結実する. 1900 年に『哲学雑誌』166 号の付録として刊行された『日本現時学生の宗教心に関する 調査の報告』がそれである。調查報告書によれば，当初は数十名を対象としていた 計画に対し，助言を求められた元良が質問項目を作成，また高等教育を受けている 学生全般に対象を広げることを提案したという。結果として総計 4,561 通の質問書 が作成，郵送され，942の回答を得，報告書が刊行された。元良は報告書において， 第 1 章「調查の結果に就ての注意」の執筆を担当している（元良 1900）. 調査結果 の詳細についてはここで立ち入らないが，元良は統計の重要性を訴えるだけでなく， 実際に社会調查の企画に携わり, 統計を用いた実証の学としての社会学の定着に努 めた.

社会学研究会では, 学問としての社会学の探求および社会問題, 社会改善策の研 究が中心に据えられる一方で, 実証的な手法による社会学の個別科学化が目指され た，当時隆盛しつつあった社会主義およびマルクス主義の立場からすれば, 社会学 研究会が漸進的な改良主義と科学主義をとったことは, 後退と受け止められかねな い（河村 1973: 189; 高橋 1965：498-9). しかしながら社会学研究会は, 心理学的 社会学や統計による実証的な研究手法の導入を図ることによって, 当時主流派だっ たスペンサー社会学の再解釈による国家主義的社会学とも一線を画すことになった. このとき社会学研究会に扔いて, 心理学的社会学と統計の導入の両面から議論の基 礎を提供したのが元良だったといえよう.

\section{5 社会学史における元良勇次郎}

ここまで述べてきたように，社会学史において元良が果たした役割は，当時の主 流派とは一線を画した心理学的社会学, および統計を用いた実証的な研究手法の導 入とみなすことができる. 秋元律郎によれば, 心理学的社会学の導入の意義は, 「建部流の社会有機体説から社会学を解き放ち, 個別科学としての社会学の樹立の 
道をつけていったこと」（秋元 1979：128）に求められる. スペンサーの社会有機 体説を曲解した国家主義的社会学に対し, 元良はギディングスの翻訳や社会学研究 会への参加を通じて, まず心理学的社会学の導入を進めた. また統計の重視も特筆 すべき点で，単なる外来の学説の紹介にとどまらず，日本社会を対象とする実証的 な研究を推進した点も記憶されてしかるべきであろう.

本稿冒頭で紹介した論文において高橋徹は, 元良が導入した明治期の心理学的社 会学について,「自然法的民権論の依拠する『個人主義的, 原子論的アプローチ』 と, 国権主義の依拠する『集合主義的, 全体論的アプローチ』とを調整して, 『第 三の可能性』を提出している」点を積極的に評価する一方, それがあくまで制度内 の改良主義にとどまったことを批判している（高橋 1965：479）. 確かに，「市民社 会建設の無窮動的改革」（高橋 1965：479）を目指す立場からすれば,「着実温厚の 議論」に徹し, 漸進的な社会改善を目指す元良の試みは不十分で微温的なものと映 るかもしれない. またその学説は, 現在の視点からみて多くの点で限界を有してい ることも事実である. しかし当時の文脈からすれば，社会学研究会の設立を含む元 良の活動と, 主流の社会有機体説に対する批判的役割には適切な評価を与えるべき である。

また，これまでの研究において論じられてきた，外山や建部らによるスペンサー を経由したイギリス社会学の受容, 西周によるコントの紹介を通じたフランス社会 学の導入, ヘーゲル読解を経由したドイツ社会学の受容と並び, アメリカ社会学お よび心理学的社会学の日本への導入において元良が果たした役割, あるいは遠藤や 高木，樋口など後進に与えた影響についても再評価を要する. 社会学に焦点を当て た論文で学位を取得し, 帰国後も一貫して社会学の紹介と定着に努めたことを考え 合わせると, アーネスト・フェノロサ, 外山とはまた異なった「日本社会学の源流 の 1 つ」とえみなすことができるだろう.

加えて本稿で明らかにしたのは, 留学前後に元良は, 社会学の個別科学化を担っ た心理学的社会学とも異なる, 交換を基礎とした総合的な社会理論を構想していた 点である. 元良において, 実験心理学と社会学, 感覚の理論と社会の理論はともに 総合的な「社会の学」のなかに位置づけられる.こうした視点を有していたからこ そ, 元良は社会学と心理学の制度化の双方にかかわりつつ, しかも当時の主流派の 社会学とは異なる方向を明確に打ち出し得た. 本稿では元良の膨大な業績のなかか ら，社会学史に関連する活動を紹介するのみにとどまったが，他領域を含めたより 広範な影響関係の解明については, 今後の課題としたい.

\section{[注]}

1）以降, 引用に際しては, 旧字体の一部を新字体に, 歴史的仮名遣いを現代仮名遣いにあらた め, また難読漢字やカタカナ表記の一部を平仮名にあらためた.

2）ホールはハーバード大学でウィリアム・ジェイムズらの指導の下, アメリカで初めての心理 学博士を取得し, その後ライプツィヒ大学でヴィルヘルム・ヴントのラボに所属している. 
1883 年にはジョンズ・ホプキンス大学にアメリカで初めての心理学実験室を開設したことでも 知られており，したがって元良は，当時草創期にあったアメリカ心理学の最先端の潮流に身を おいていた.

3）イリーは元良が博士号を取得した翌年，明治期の社会運動にも大きな影響を与えた『キリス 卜教の社会的側面』（Ely 1889）を上梓している.

4）元良は愛国心と社会的感覚の違いを指摘しているものの（元良 1890: 189），その議論のなか で，社会と国家，あるいは民族や種族が混同されている場合がある点には注意が必要である.

\section{[文献]}

秋元律郎, 1979, 『日本社会学史——形成過程と思想構造』早稲田大学出版部.

荒川歩, 2000,「ジョンズ・ホプキンス大学入学以前の元良勇次郎」『心理学史・心理学論』2: 1723.

Ely, Richard Theodore, 1889, Social Aspects of Christianity: And Other Essays, New York: Thomas

Y. Crowell.

遠藤隆吉, 1907, 『近世社会学』成美堂.

一, 1908, 『社会心理と教育』成美堂.

Giddings, Franklin Henry, 1896, The Principles of Sociology: An Analysis of the Phenomena of Association and of Social Organization, New York: Macmillan \& Co. $(=1900$, 遠藤隆吉訳 /元 良勇次郎閲『社会学』東京専門学校出版部. )

Hall, Stanley, and Motora, Yuzero, 1887, “Dermal Sensitiveness to Gradual Pressure Changes,” The

American Journal of Psychology, 1: 72-98.

樋口秀雄, 1912, 『社会学十回講義』二松堂.

川合隆男・竹村英樹編, 1998, 『近代日本社会学者小伝——書誌的考察』勁草書房.

河村望, 1973, 『日本社会学史研究 (上)』人間の科学社.

小林郁, 1909, 『社会心理学』博文館.

故元良博士追悼学術講演会編, 1913, 『元良博士と現代の心理学』弘道館.

元良勇次郎, 1884, 『教育新論』中近堂.

—, 1889a，「社会の道徳と自殺との関係」『文』2(2): 76-90.

—, 1889b, 「心理学と社会学の関係」『哲学会雑誌』2(24): 701-22.

—, 1889c, 「富と道徳」『国民之友』44: 15-20.

—, 1890, 『心理学』金港堂.

—， 1891, 「社会学の範囲及び性質」『哲学会雑誌』5(53)：1005-19.

—， 1893，「青年会に於て」『日本大家論集』5(4)：24-33.

—, 1895, 「社会心理学」『龍門雑誌』83: 11-17.

—, 1897a, 『心理学』敬業社.

—, 1897b, 『心理学十回講義』富山房.

—, 1899, 「生活の標準」『社会』1-1: 10-25.

—, 1900, 「日本現時学生の宗教心に関する調查の報告」『哲学会雑誌』166 付録.

—, 1907, 『心理学網要』弘道館.

—, 1911, 「個人意識と社会意識」『哲学雑誌』26(288) : 1-19.

Motora, Yuzero, 1888, “Exchange, Considered as the Principle of Social Life," Ph.D. dissertation, Johns Hopkins University. 
日本心理学会編, 1980, 『日本心理学会五十年史 (第 1 部)』金子書房.

大泉博，2013，「凡例」『元良勇次郎著作集』刊行委員会編『元良勇次郎著作集 第 1 巻』クレス出版, vii-xvi.

大山正，2001，「わが国における精神物理学の導入一元良勇次郎の『精神物理学』をめぐって」 『心理学評論』44(4) : 422-32.

苧阪直行編, 2000, 『実験心理学の誕生と展開—実験機器と史料からたどる日本心理学史』京都 大学学術出版会.

苧阪良二, 1998, 「明治から昭和初期にいたる実験心理学の形成過程一一元良勇次郎と松本亦太郎 を中心として」『心理学評論』41(3)：333-58.

Piovesana, Gino K., 1963, Recent Japanese Philosophical Thought, 1862-1962: A Survey, Tokyo: Enderle Bookstore. (=1965, 宮川透・田崎哲郎訳『近代日本の哲学と思想』紀伊國屋書店).

佐原六郎, 1968, 「黎明期の日本社会心理学——元良勇次郎と社会心理学の萌芽」『慶応義塾大学大 学院社会学研究科紀要』8: 1-10.

一, 1987, 『社会学と社会心理学』慶應通信.

佐藤達哉, 2002, 『日本に扔ける心理学の受容と展開』北大路書房.

志邨晃佑，1993，「革新主義改革と対外進出——世紀転換期のアメリカ社会」有賀貞・大下尚一・ 志邨晃佑・平野孝編『アメリカ史 $2-1877$ 1992』山川出版社, 101-95.

高橋徹, 1965, 「日本に打ける社会心理学の形成」高橋徹・富永健一・佐藤毅編『社会心理学の形 成』培風館, 317-505.

武邦保，1978，「リチャード・イリー（Richard T. Ely, 1854-1943）ノート——メリカの教会人と 社会運動（その 1)」『同志社アメリカ研究』14: 86-92.

谷本富, 1908, 『群衆心理の新研究』六盟館.

徳谷豊之助, 1906, 『社会心理学』誠之堂.

東京大学文学部社会学研究室編, 1954, 『東京大学文学部社会学科沿革七十五年概観』東京大学文 学部社会学研究室開室五十周年記念事業実行委員会.

塚原政次，1900，『ルボン氏民族心理学』育成会.

宇賀博, 1976, 『「社会科学」から社会学へ——メリカ社会学思想史研究』恒星社厚生閣. 1990, 『アメリカ社会学思想史』恒星社厚生閣.

（原稿受付 2016.12.17 掲載決定 2018.3.25） 


\title{
Yujiro Motora and His Role in the History of Japanese Sociology: \\ The Interplay between Sociology and Experimental Psychology \\ in the Late Nineteenth and Early Twentieth Century
}

\author{
OKUBO, Ryo \\ Aichi University \\ okubo@vega.aichi-u.ac.jp
}

Yujiro Motora (1858-1912) was the first professor of psychology at Tokyo Imperial University, and is known as the pioneer of Modern Psychology in Japan. However, his Ph.D. dissertation, titled "Exchange, considered as the principle of social life," submitted to Johns Hopkins University in 1888 , focused on social science and sociology. Moreover, he wrote numerous papers on sociology, social psychology, and social surveys after his return from the United States, and in the end, joined the important Japanese association for sociology in the Meiji period, "Society for the Study of Sociology (syakaigaku kenkyukai)," as one of its founders in 1898.

In this article, I will focus on an as-yet-unknown aspect of the sociological work of Motora, and try to reconstruct his concept of the "science of society" from the fragments of his voluminous writings. I will examine Motora's role in early Japanese sociology, in outline, and give an introduction to the idea of psychological sociology and empirical research methods based on statistics. In his incomplete conception, both experimental psychology and sociology, or the theory of sense and the theory of society, are situated within a comprehensive "science of society." His stance functioned as a critical comment on mainstream sociology of those days, such as Tongo Takebe's curious contamination of his nationalistic sociology and Herbert Spencer's concept of society as an organism. Further, he endeavored to conduct the earliest stages of social surveys in Japan, and was influential on younger sociologists.

My research shows that, while Yujiro Motora was called a "pioneer of Japanese psychology" in previous research, his achievement should be evaluated as "one of the sources of Japanese sociology."

Key words: Yujiro Motora, Psychological Sociology, History of Japanese Sociology

(Received Dec. 17, 2016 / Accepted Mar. 25, 2018) 